\title{
The Sources of Stress amongst Construction Consultants in Workplace Environment
}

\author{
Nurul Afida Isnaini Janipha, Faridah Ismail \\ Faculty of Architecture, Planning and Surveying, \\ Universiti Teknologi MARA, Shah Alam, MALAYSIA \\ nurulafida@salam.uitm.edu.my
}

\begin{abstract}
Designers in Malaysia are beginning to feel the existence and growing of stress levels at the workplace due to high pressure and competitive working environment. Designer profession is to create inspire designs that sometimes lead to stress and affect their work performance. Moreover, stress can cause poor planning, lack of communications and interpersonal conflicts. Therefore, the objective of this paper is to identify the causes and effects of workplace stress amongst designers. Questionnaire survey was distributed among 500 designers. The respondents are from construction consultant companies in Klang Valley. The response rate of this paper was performed of about $38 \%$ of the samples. The outcome of this research show that they were generally enjoyed their work but sometimes feel stress due to poor planning and job demand, working surrounding and relationship among staff. This indicates that stress lead to bad designs and sometimes gives bad effects to the performance of the designers.
\end{abstract}

Keywords: Workplace Stress; Causes; Effetcs Designers

eISSN 2514-751X @ 2018. The Authors. Published for AMER ABRA cE-Bs by e-International Publishing House, Ltd., UK. This is an open-access article under the CC BY-NC-ND license (http://creativecommons.org/licenses/by$n c-n d / 4.0 /)$. Peer-review under responsibility of AMER (Association of Malaysian Environment-Behaviour Researchers), ABRA (Association of Behavioural Researchers on Asians) and CE-Bs (Centre for EnvironmentBehaviour Studies), Faculty of Architecture, Planning \& Surveying, Universiti Teknologi MARA, Malaysia.

DOI: https://doi.org/10.21834/aje-bs.v3i9.306 


\subsection{Introduction}

Designers, i.e. Architects and Interior Designers are appointed by the client to investigate all alternative approaches, creating models and laying out simple design to complicated buildings. Designers must creatively act in transforming the building concept in forms of architectural vision. Moreover, designers must have an understanding on many aspects that involved with consultation and technical aspect of architectural, have knowledge on the buildings codes, creating work strategies and others (Bredemeyer \& Malan, 2006: Wall, 2011). This multiple task of designers' job sometimes gives burden to them and will cause workplace stress.

Stress does occur amongst designers when they are encounter with uncooperative people in getting their job completed. Additionally, the rising of the deadline pressure and increasing challenges in management in the modern workplace have led to stress.

Hence, consultants especially designers need to recognise what stress is and how the stress can affect them because stress can come from any situations. Ahmad (2008) indicated that at least $20 \%$ of the 27 million people in the country suffer from degree of stress. Basically, there is no specific definition of stress because individuals react to it differently. Pressure can lead to stress at home and workplace. Stress at the workplace can lead to major problems to the organization as well as for the workers. There are many factors of stress affecting designers such as, burden of works and projects, the catching of deadlines, the long working hours, the collaboration, coordination, integration process with other parties especially with clients'. These factors of stress could affect the organization quality of work and also life of the individuals, i.e. workers. All of these combined factors can cause emotional disturbances and can lead into stress.

\subsection{Workplace Stress}

Stress occurs when there is a relationship between the person and the environment. It appraised by the person that exceeding their resources or working ability and endangering their well-being (Lazarus \& Folkman, 1984). CIOB (2006) defines stress at the workplace as "the adverse reaction people have to excessive pressure or other types of demand placed on them". Besides, through an online survey by CIOB (2006) showed that $70 \%$ of construction professionals felt that stress was a factor for poor retention levels in the construction industry. Generally, job stress can be seen as physical and emotion response to risky and poor working conditions in which job requirement exceed the capabilities, resources or needs of the worker.

\subsection{Factor Causes Workplace Stress}

In any job, there are a large number of environmental sources of work stress. Table 1 show the factor causes stress at the workplace.

Table 1: Factor Causes Stress at the Workplace

\begin{tabular}{|c|c|}
\hline \multicolumn{1}{|c|}{ Factors } & Descriptions \\
\hline Characteristic of the work itself & Uncomfortable working place/poor work environment, \\
\hline
\end{tabular}


Janipha, N.A.l., \& Ismail, F. / Asian Journal of Environment-Behaviour Studies (ajE-Bs), 3(9) Jul / Aug 2018 (p.201-208)

\begin{tabular}{|l|l|}
\hline & $\begin{array}{l}\text { extreme temperature, loud noise, poor lighting, foul } \\
\text { smells, badly designed office equipment }\end{array}$ \\
\hline The attitude of the person and/or organisations & $\begin{array}{l}\text { Depressed mood, lowered self-esteem, life } \\
\text { dissatisfaction, job dissatisfaction }\end{array}$ \\
\hline Career development pressure & $\begin{array}{l}\text { Uncertain job security, fear of layoff, intention to leave } \\
\text { the job }\end{array}$ \\
\hline The climate and structure of the organisation & $\begin{array}{l}\text { Uncertainty and mismatch at work, uneven } \\
\text { distributions of workload among project participants }\end{array}$ \\
\hline Nature of relationship at workplace & Disrespect or distrust among project team members \\
\hline $\begin{array}{l}\text { Problem associated with the interface between the } \\
\text { organisation and the outside world }\end{array}$ & $\begin{array}{l}\text { Poor communications, poor relationship within workers } \\
\text { in the organisation and affiliation among project } \\
\text { participants }\end{array}$ \\
\hline
\end{tabular}

Sources: Janipha \& Ismail (2012); Jerold (1996); Kornhauser (1965); Cooper (1981); Williams (2003)

\subsection{Effects of Workplace Stress}

Stress affects different people in different ways, and the experience of work stress can cause unusual and dysfunctional behaviour at work and contribute to poor physical and mental health. Table 2 indicate the effects of workplace stress.

Table 2: The Effects of Workplace Stress

\begin{tabular}{|l|l|}
\hline \multicolumn{1}{|c|}{ Effects } & \multicolumn{1}{|c|}{ Descriptions } \\
\hline Illness and diseases & $\begin{array}{l}\text { Increase coronary heart disease, higher blood } \\
\text { pressure, obesity, smoking, hypertension, diabetes, } \\
\text { peptic ulcers }\end{array}$ \\
\hline Absenteeism and poor job performance & $\begin{array}{l}\text { Lack of concern for their colleagues, disrespect, } \\
\text { distrust, dislike of those they are working with, lots of } \\
\text { frustration }\end{array}$ \\
\hline Burnout & $\begin{array}{l}\text { Changes in the social life, avoid communicating with } \\
\text { people at work, attitude to work, i.e. low motivation and } \\
\text { commitment, frequent grumbling about low } \\
\text { accomplishment }\end{array}$ \\
\hline Organisational ineffectiveness & $\begin{array}{l}\text { Poor decision making ability, increase error in making } \\
\text { judgement, reduced ability to do complex tasks and } \\
\text { planning, reduce communication skills and ability to } \\
\text { handle stress on the job, reduced productivity and } \\
\text { performance }\end{array}$ \\
\hline $\begin{array}{l}\text { Financial impact, poor employee performance, } \\
\text { absenteeism from project meetings, leaving the } \\
\text { company }\end{array}$ \\
\hline
\end{tabular}

Sources: Janipha \& Ismail (2012); Baker (1985); Russek \& Linda (1977); Heaney \& Ryan (1990); Jackson \& Schuler (1985); Defrank \& Cooper (1987); Holt (1993); Wan Hussin (2007); Leung et al. (2005); Jamal (1984); Varhol (2000)

\subsection{Research Methodology}

The Questionnaire Survey method is chosen for collecting data for this paper. The questionnaires were distributed to the architect and interior design firms. The information required from the respondents is mainly to identify and investigate the causes and effects of stress in designers' profession at the workplace. The overall target population of this study is 
those who work as a designer in Klang Valley area. A total of 500 questionnaires were sent out to design-based firms. The targeted firms were mainly located in the Klang Valley area. A total of 190 responses were received within the time limits established. This represented a response rate of $38 \%$.

\subsection{Research Analysis and Findings}

\subsection{Causes of Workplace Stress}

The outcome showed that even though most of the consultant firms do provide mental health trainings and seminars in the workplace, the main contributory factor of stress for designers is still having a problem at work compared to having a problem at home. This is supported in the research done by Janipha \& Ismail (2012), the job as designers sometimes give dissatisfaction, but they generally enjoy their job, which contributed to $53 \%$. However, $23 \%$ of respondents indicated that work as a designer was difficult.

For the cause of problems at works surrounding, most of the respondents $(24 \%)$ were strongly agreed that poor ventilation was the main cause of the problem at work surrounding. $23 \%$ of respondents agreed that noise was the cause of the problem at work surrounding. The results show that the working environment was very important for designers and noise may contribute to a higher level of stress. For poor/inadequate lighting, $23 \%$ of respondent stated that they were moderately agreed that this factor was the cause of the problem at work surrounding. There was similar percentage of respondents that strongly agreed the excessive heat and overcrowding were the cause of the problem at work surrounding.

Most of the respondents disagree to poor relation with supervisor $(22 \%)$, poor relation with workmates $(26 \%)$ and working with the public $(30 \%)$ that cause problem of stress at workplace. However, for other working relationship, such as harassment and/or humiliation (24\%), impersonal treatment which up to $31 \%$ and lack of communication, consists of $23 \%$ were moderately agreed that this type of working relationships may cause a problem at the work place. This will lead to stress at the workplace.

Additionally, the nature of organisational is one of factor affecting workplace stress, which consists of inadequate staff in the department or project team, poor communication among team member, poor planning, lack of job feedback, interpersonal conflicts, poor relations with supervisor and bullying. Research highlighted that most of the respondents were strongly agreed to poor planning. This was the main factor contributed to workplace stress. Next, the respondents agreed to lack feedback and moderately agreed to the factors of bullying in the workplace stress. Majority of the respondents were disagreeing to the factors of insufficient training and poor relations with superiors that lead to workplace stress.

For the factor of job demand, majority of the respondents contribute to $21 \%$, were strongly agreed that too much work given to them may affect workplace stress while $26 \%$ agreed that hours worked given to complete the job and ambitious deadline affect workplace stress. Moreover, findings indicated that $26 \%$ of respondents were moderately agreed to workplace stress occur when working in isolation. However, there were respondents that disagreed to 
the factor of too little work given (24\%) and strongly disagreed for the factor of insufficiently skilled for the job given $(23 \%)$ that affected workplace stress.

Overall, majority respondents (38\%) sometimes feel underpaid by their organisation. This was because most of the respondents have between 2 to 5 years working experiences as designers. Nevertheless, $33 \%$ of respondents stated that they never being undervalued on the job given and does mentioned they often receive appreciation for good work they have done.

\subsection{Effects of Workplace Stress}

Table 3: Overall Responses of Causes and Effects of Stress in the Workplace by Respective

Respondents

\begin{tabular}{|l|l|}
\hline Causes of Stress in Workplace & Effects of Stress in Workplace \\
\hline & \\
\hline PROBLEM AT WORK SURROUNDING & TIME OFF DUE TO STRESS \\
\hline Poor ventilation & A day off \\
\hline Noise & One week \\
\hline Excessive heat & One month \\
\hline Overcrowding & \\
\hline Poorlinadequate lighting & JOB PERFORMANCE \\
\hline & Sometimes gives bad effects to design/working performance \\
\hline WORKING RELATIONSHIP & No affects at all \\
\hline Lack of communication & Working performance getting poor \\
\hline Impersonal treatment & Cannot produces the best output to design job \\
\hline Harassment & \\
\hline Poor working relationship with the public & SYMPTOM OF STRESS \\
\hline Poor relation with workmates & Continual tiredness \\
\hline Poor relation with supervisor & Sleeplessness \\
\hline & Frequently headache \\
\hline ORGANISATIONAL FACTORS & Depression \\
\hline Poor planning & Anxiety \\
\hline Lack of feedback & Indigestion \\
\hline Bullying & \\
\hline $\begin{array}{l}\text { Poor communication among team members Inadequate } \\
\text { staff to teams or department }\end{array}$ & UNDER STRESS BEHAVIOURAL \\
\hline Insufficient training & Feel very tired \\
\hline Interpersonal conflicts & Cannot sleep \\
\hline Poor relation with supervisor & Job burnout \\
\hline & Increase job tension \\
\hline JOB DEMAND & Feel angry \\
\hline Too much work & Lower self-confident \\
\hline Hours to work (working time) & \\
\hline Ambitious deadline & \\
\hline Working in isolation & \\
\hline Insufficient skills for the job given & \\
\hline Too little work & \\
\hline & \\
\hline PERCEPTION ON JOB GIVEN & \\
\hline Underpaid for the job given & \\
\hline Undervalued the job given & \\
\hline Receive appreciation for good work & \\
\hline & \\
\hline
\end{tabular}


Outcome of the research stated that $54 \%$ of respondents stress by the work given to them compared to $45 \%$ said no. Conversely, there were slightly different of opinion to the level of stress. Only $48 \%$ indicated that level of stress did cause harm to them, whereas others responded otherwise. Stress also affected the organization and as mentioned by Janipha and Ismail (2012), almost all respondents agreed that having stress at the workplace affected the organization.

The research also shown that $55 \%$ of respondents did take time off due to stress and the longest period they take of about one month. However, most of the respondents only take a day off $(47 \%)$ or take off for one week $(34 \%)$ due to stress at the workplace.

For the effect on job performance, majority of respondents said sometimes it give effects to designs or work performance. Others stated that when they were in stress, they cannot produce best to design job and working performance getting poor. $33 \%$ of respondents indicated that when they were in stress, their job performance have no effect at all.

There were several symptom of stress occurred in workplace consists of headache, depression, anxiety, sleeplessness, continual tiredness and indigestion of food consumption. The highest response was continual tiredness (55\%), followed by sleeplessness $(54 \%)$, frequently headache $(53 \%)$, depression $(47 \%)$, anxiety $(46 \%)$ and indigestion $(45 \%)$.

Stress at the workplace also affected the designers behavioural. For under stress behavioural factor, $26 \%$ were strongly agreed that when they were under stress, they feel very tired and having job burnout. An average of $23 \%$ respondents indicated that they disagreed to increase in job tension, when they were in a stress situation.

Table 3 highlighted the overall responses of causes and effects of stress in the workplace by respective respondents.

\subsection{Conclusion}

There is no a specific term or definition of stress as different individual and/or organization has their owned definition. However, stress is always related to a particular feeling of individuals, in which the demands or ability of work and/or life exceed the belief of the individual in his or her capacity to cope. Stress is related to a relationship between the working environment and the person himself. One of the causes of stress in the workplace is addressing adequate mental health trainings and seminars in the organization. Moreover, other factor or causes of workplace stress consists of adequate facilities in the organization i.e. lighting, ventilation, etc., and working environment i.e. harassment and/or humiliation, impersonal treatment and lack of communication. Apart from that, cause of stress comes from the organisational activities such as lack of feedback, poor in planning and bullying. Job demand factor will increase stress in the workplace, for example, too much work given to staff at the same time and striving to cope with the deadline.

Most of the designers agreed that feel that if the staffs are in stress, they will affect the overall organization performance. Furthermore, the level of stress does cause harm to them. The effect of stress to designers is based on their job performance. They are likely shows poor job performance and this give bad effect to design or tasks given (cannot produce good design). To certain extent, sometimes stress affect the working performance, which the 
situation is getting worse. Designers who are stressed are also tending to be unhealthy, less productive, poorly motivated and feel insecure at work. Their organizations are difficult to be successful in a competitive market. Even though designers cannot usually protect themselves or their organisation from stress arising outside of work, but they can defend themselves from stress that arises through proper work planning and management. Stress at the workplace can be a major problem to the organization as well as for its workers. Good management and good work organisation are the best forms of stress prevention.

\section{Acknowledgement}

A highly appreciation to Research Management Institution (RMI), Universiti Teknologi MARA for funding the research and to all people that involves directly and indirectly in the success of this research. Special acknowledgement goes to the reviewers for their reviews and comments on this paper.

\section{References}

Ahmad, A.L. (2008). Work Place Stress. Retrieved from: http://www.cdc.gov/niosh/stresswk.html

Baker, D.B. (1985). The Study of Stress at Work. Annual Review of Public Health, 6. 367-381

Bredemeyer, D. \& Malan, R. (2006). The Role of Architect. Retrived from http://www.bredemeyer.com/pdf_files/role.pdf

CIOB. (2006). Occupational Stress in the Constuction Industry. Retrived from http://www.ciob.org.uk/resources/publications

Cooper, C. L. (1981). The Stress Check. Prentice Hall Inc. London

Defrank, R. S., \& Cooper, C. L. (1987). Worksite Stress Management Interventions: Their Effectiveness and Conceptualization, Journal of Managerial Psychology, 2, 4-10

Heaney, C.A.\& Ryan, M. V. (1990). Broadening the Scope of Worksite Stress Programmes: A Guiding Framework. American Journal of Health Promotion. 4. 413-20

Jackson, S. \& Schuler, R. (1985). A Meta-Analysis and Conceptual Critique of Research on Role Ambiguity and Role Conflict in Work Setting. Organizational Behavior and Human Decision. 36. 16-28

Janipha, N.A.I \& Ismail, F. (2012). Workplace Stress Amongst Consultant in Practice. Proceedings ASIA Pacific International Conference on Environment-Behaviour Studies, Cairo. 31 October - 2 November 2012

Jerrold, S.G. (1996). Comprehensive Stress Management. University of Maryland. 7

Kornhauser, A.(1965). Mental Health of the Industrial Worker. New York: Willey

Lazarus, R.S. \& Folkman, S.(1984). Stress, Appraisal and Coping. New York:Springer

Russek, H. I. \& Linda G. R. (1977). Is Emotional Stress and Ethological Factor in Coronary Heart Disease? 
Janipha, N.A.I., \& Ismail, F. / Asian Journal of Environment-Behaviour Studies (ajE-Bs), 3(9) Jul / Aug 2018 (p.201-208)

Psychomatics. 17.63

Varhol, P. (2000). Identify and Manage Work-related Stress. Electronic Design. 48(26). 123-124

Wan Hussin, W.M.A. (2007). Managing Stress by Changing Demands to Preferences. The Malaysian Surveyor. 3942

Williams, C. (2003). Sources of Workplace Stress. Perspectives on Labour and Income. Statistics Canada Catalogue no. 75-001-XIE. 4(6). 5-12. Retrieve from http://www.statcan.ca/english/freepub/ 